\title{
REVIEW ARTICLE Parvalbumin interneuron vulnerability and brain disorders
}

\author{
Jacob B. Ruden (iD), Laura L. Dugan ${ }^{1,2}$ and Christine Konradi (iD) $1,3,4$
}

Parvalbumin-expressing interneurons (PV-INs) are highly vulnerable to stressors and have been implicated in many neuropsychiatric diseases such as schizophrenia, Alzheimer's disease, autism spectrum disorder, and bipolar disorder. We examined the literature about the current knowledge of the physiological properties of PV-INs and gathered results from diverse research areas to provide insight into their vulnerability to stressors. Among the factors that confer heightened vulnerability are the substantial energy requirements, a strong excitatory drive, and a unique developmental trajectory. Understanding these stressors and elaborating on their impact on PV-IN health is a step toward developing therapies to protect these neurons in various disease states and to retain critical brain functions.

Neuropsychopharmacology (2021) 46:279-287; https://doi.org/10.1038/s41386-020-0778-9

\section{PARVALBUMIN INTERNEURONS ARE IMPLICATED IN A VARIETY OF NEURO-PSYCHIATRIC DISEASE STATES}

Injury to, or dysfunction of, parvalbumin inhibitory interneurons (PV-INs) has been proposed to contribute to the pathophysiology of several important neuro-psychiatric disorders, including schizophrenia, autism spectrum disorder (ASD), bipolar disorder (BPD), various neurodegenerative diseases, and even aging-related cognitive changes. In this review, we will briefly summarize the literature implicating PV-IN deficits in neuro-psychiatric conditions and discuss specific properties of these neurons that may make them selectively vulnerable to multiple stressors, including the complex developmental pathways required for normal development of PV-INs and circuits. Emerging literature suggests that approaches to preserve function of these unique inhibitory neurons have benefits for both acute and chronic brain disorders.

Extensive accounts in the literature point to PV-IN-related changes in individuals with schizophrenia [1-4], a finding that is supported by various animal models that recapitulate aspects of the disease [5-7] (Table 1). In schizophrenia, lower levels of PVALB mRNA, the gene coding for PV, were seen in the hippocampus and layer 4 of the dorsolateral prefrontal cortex, which might be partially explained by DNA hypermethylation [1, 8]. Reductions in the number of PV-INs were reported in the hippocampus, entorhinal cortex, and subicular areas [1, 9-11]. Furthermore, individuals with schizophrenia have a lower density of excitatory synapses on PV-INs [12] and exhibit alterations in gamma oscillations during a working memory task [13]. Animal models that mimic schizophrenia replicate the loss of PV-INs in the hippocampus $[6,14,15]$, and show a loss of PV fluorescence per cell in prelimbic regions [16]. Interestingly, early intervention during the prepubertal period might prevent loss of PV-INs, as shown in the methylazoxymethanol acetate (MAM) rat model of PV-IN loss in the ventral hippocampus [17]. While these findings point to a pathology in PV-INs, they cannot differentiate between loss of neurons or loss of PV expression. Some human and animal model data suggest that formerly PV-INs are still present but cease to express PV, though a definitive conclusion cannot be drawn at this point $[7,18-20]$.

Alzheimer's disease (AD) is also associated with changes in fastspiking interneurons (Table 2). Transgenic mice with AD-like pathology were found to have reduced gamma power that, in one model, precedes cognitive impairment and amyloid plaque formation [21, 22]. Interestingly, amyloid plaques were reduced when hippocampal PV-INs artificially produced gamma oscillations in optogenetics paradigms [21]. Theta-gamma oscillation phaseamplitude cross-frequency coupling was impaired prior to neuronal loss or maximum tau pathology in a tau seeding model with AD-like pathology [23]. Evoked gamma oscillations to auditory stimuli were also disrupted in this model [23]. Separately, a voltage-gated sodium channel $\left(\mathrm{Na}_{\mathrm{v}} \mathrm{1} .1\right)$ that is largely found on axons of PV-INs was decreased in a mouse model with amyloid pathology, and in AD patients [24-26]. Restoration of the levels of this voltage-gated sodium channel increased gamma oscillations, while memory deficits and premature deaths decreased [26]. Furthermore, abnormalities in the default mode network, which is regulated in part by PV-INs [27], have been observed in $A D$ patients [28-32].

Reports of changes of PV-INs in AD are not without controversy. For example, decreases in the number of PV-INs in the hippocampus were observed in two mouse models of $A D$ $[33,34]$, while an increase in hippocampal PV immunoreactivity was observed in another [35], and no change in the number of hippocampal PV-positive interneurons was observed in yet another model [36]. These contradicting observations may be explained by the different mouse models used in each study. In AD patients, however, a decrease in PV-INs was reported in the dentate gyrus, and an increase in PV-INs was reported in the piriform cortex $[34,37,38]$. The different findings reported in each study could be due to the different brain regions examined. Indeed, it would be surprising to find that PV-IN densities in disease are uniform across every brain region given that fast-spiking interneurons have different functions in different brain areas.

\footnotetext{
${ }^{1}$ Vanderbilt Brain Institute, Vanderbilt University, Nashville, TN, USA; ${ }^{2}$ Division of Geriatric Medicine, Department of Medicine, Vanderbilt University Medical Center, Nashville, TN USA; ${ }^{3}$ Department of Pharmacology, Vanderbilt University, Nashville, TN, USA and ${ }^{4}$ Department of Psychiatry, Vanderbilt University, Nashville, TN, USA Correspondence: Christine Konradi (christine.konradi@vanderbilt.edu)
}

Received: 8 April 2020 Revised: 2 July 2020 Accepted: 21 July 2020

Published online: 28 July 2020 
Table 1. PV-IN alterations in schizophrenia and associated animal models.

\begin{tabular}{|c|c|c|}
\hline PV alteration & Described in & References \\
\hline Reduced number of PV-INs in medial prefrontal cortex & Animal models & {$[3,20]$} \\
\hline Reduced number of PV-INs in hippocampus & ${ }^{\text {a}} S Z$; animal models & {$[1,6,7,14]$} \\
\hline Reduced number of PV-INs in caudal entorhinal cortex & SZ & [9] \\
\hline Reduced number of PV-INs in parasubiculum & SZ & [9] \\
\hline Reduced PV immunoreactivity in PV-INs in prefrontal cortex & Animal model & {$[16,19]$} \\
\hline Reduced PV immunoreactivity in anterior cingulate cortex & Animal model & [93] \\
\hline Reduced PV mRNA expression in hippocampus & SZ & {$[1]$} \\
\hline Reduced PV mRNA expression in prefrontal cortex & SZ & {$[10,11]$} \\
\hline Reduced excitatory synapse density on PV-INs & SZ & {$[12]$} \\
\hline Decreased density of PV-INs expressing GluN2A mRNA in prefrontal cortex & SZ & [126] \\
\hline Increased PV methylation in hippocampus & SZ & {$[8]$} \\
\hline Increased gamma oscillatory activity during working memory & SZ & [13] \\
\hline Gamma power deficit in medial prefrontal cortex & Animal model & [5] \\
\hline Decreased perineuronal net labeling around PV-INs in dorsolateral prefrontal cortex & SZ & [19] \\
\hline
\end{tabular}

ASD shares many overlaps with schizophrenia, not just on a clinical scale, but also with similar PV-IN abnormalities [39]. The Df (16)A \pm transgenic mouse and the $\operatorname{LgDel}( \pm)$ mouse, both of which model the 22q11.2 deletion in humans [5, 40-43], the contactin associated protein 2 mouse [44-46], the neurexin transgene model [47], Shank models [20, 48-50], and platelet-derived growth factor receptor-beta (Pdgfrb) knockout mouse [51, 52] are examples of models for both ASD and schizophrenia, which have large effects on PV-IN function. In other mouse models of ASD, a reduction in PV-INs or a decrease in PV immunoreactivity has been reported [20]. Concurrently, PV knockout mice display behavioral phenotypes that resemble core behavioral phenotypes found in humans with ASD [53]. One of the best described ASD models, knockout of the gene responsible for Rett syndrome, methyl CpG binding protein 2 (Mecp2), shows repetitive behaviors and stereotypies even if the gene is selectively removed from INs only [54].

Schizophrenia also shares significant overlap with BPD $[55,56]$, including PV-IN pathology. Mouse models relevant for both disorders, including the disrupted in schizophrenia 1 gene (Disc1) [57-61], or brain derived neurotrophic factor (Bdnf) [62], show abnormal PV-IN function ranging from migration deficits to reduction in IN number.

But schizophrenia, AD, ASD, and BPD are not the only diseases for which PV-INs seem to play an important role. Epilepsy [63, 64] and prion disease [65] are among other disorders that are associated with alterations in PV-INs. There is therefore ample evidence that PV-INs are vital for brain function and intricately linked to brain malfunction.

\section{CHARACTERISTICS OF PV-INS}

Inhibitory GABAergic interneurons can be classified based on their co-expression of a variety of small proteins that principally function as neuromodulators or as calcium $\left(\mathrm{Ca}^{2+}\right)$-binding proteins [66]. The $\mathrm{Ca}^{2+}$-binding protein PV ("small albumin"), which is approximately $12 \mathrm{kD}$ in humans, defines one class of GABAergic interneurons. PV increases the rate of $\mathrm{Ca}^{2+}$ sequestration, reduces presynaptic $\mathrm{Ca}^{2+}$ levels, modulates short-term synaptic plasticity, and prevents cumulative facilitation (Fig. 1), $[67,68]$. Since PV rapidly sequesters $\mathrm{Ca}^{2+}$, it strongly attenuates the $\mathrm{Ca}^{2+}$-activated potassium conductance responsible for postspike hyperpolarization, which explains in part why PV-INs repolarize faster and fire faster than other neurons. For this reason, the characteristic phenotype of PV-INs is fast-spiking action potentials at high energetic costs [66].

PV-INs in the cortex are highly interconnected via electrical and chemical synapses [69]. These networks are associated with plasticity from early life throughout adulthood [70-73]. PV-INs have roles in both feedforward and feedback inhibition, regulation of sensory responses, and in learning and plasticity [66]. Individual PV-INs contact nearly every local pyramidal neuron which enables them to synchronize networks [74]. They help to create and maintain gamma oscillations, which are high-frequency waves between 20 and $100 \mathrm{~Hz}[66,75]$. Stimulation of PV-INs leads to an increase in gamma oscillation patterns, while inhibition of PV-INs or downregulation of PV at cortical synapses reduces gamma oscillations [76-78]. Gamma oscillations in humans are also associated with increased working memory load [79]. Animal studies suggest that a key mechanism of neural oscillations is through glutamatergic regulation. Indeed, PV-INs receive the greatest excitatory input of any population of inhibitory neurons in the cortex, which puts them under intense stress $[16,80]$.

\section{PV-INS HAVE UNIQUE ENERGY REQUIREMENTS THAT RENDER THEM VULNERABLE TO MANY STRESSORS}

PV-INs have extraordinary energy requirements to support a high metabolic activity and to protect against significant glutamatergic stress $[16,80,81]$. The large amounts of ATP needed to sustain gamma oscillations are supplied by a high density of mitochondria [81-83]. Studies have shown that the rate of oxygen consumption during hippocampal gamma oscillations can be equivalent to the rate of oxygen spent during a seizure [83, 84]. A substantial quantity of cytochrome $c$ and cytochrome $c$ oxidase supports the high bioenergetic needs of PV-INs [81, 85], but comes at a price as cytochrome $c$ is also central to the induction of apoptosis [86].

The high metabolic activity of PV-INs is not only explained by their physiological characteristics, but by their structural characteristics as well. In CA1 of the rat hippocampus, PV-INs have larger dendritic trees and thicker dendrites than calbindin- or calretinin-positive interneurons [80]. PV-INs have a higher density of inputs, more excitatory and inhibitory synapses, and a higher ratio of inhibitory to excitatory inputs than calbindin- and calretinin-positive interneurons [80]. In addition, PV-INs connect to many principal neurons $[74,75,87,88]$. They synchronize 
Table 2. PV-IN alterations in Alzheimer's disease and associated animal models.

\begin{tabular}{|c|c|c|}
\hline PV alteration & Described in & References \\
\hline Increased number of PV-INs in hippocampus & Animal model & {$[35]$} \\
\hline Increased number of PV-INs in piriform cortex & ${ }^{\mathrm{a}} \mathrm{AD}$ & [38] \\
\hline Reduced septohippocampal pathway synapse density on PV-INs & Animal model & {$[22]$} \\
\hline Reduced gamma activity & Animal model & {$[22,26]$} \\
\hline Impaired theta-gamma oscillation phase-amplitude cross-frequency coupling & Animal model & [23] \\
\hline Disrupted evoked gamma oscillations to auditory stimuli & Animal model & {$[23]$} \\
\hline Decreased number of neurons with intact perineuronal nets & $A D$ & [37] \\
\hline
\end{tabular}

principal neuron activity [89] and they have a great impact on the energy-intensive processes of information selection and noise removal $[66,90]$. In the MAM model of schizophrenia, reduced expression of PV-INs has been correlated with a reduction in coordinated neuronal activity during task performance in rats [6]. This observation provides a hypothesis about how loss of PV-INs might contribute to behavioral and clinical observations in neuropsychiatric disorders.

The energy requirements of PV-INs make them highly susceptible to the loss of mitochondrial membrane potential (a component of, and a proxy for, a decrease in mitochondrial function), and to metabolic and oxidative stress that accompanies disease states [81,91]. In rodent models that recapitulate aspects of brain disorders, higher oxidative stress consistently correlates with decreased PV-positive cortical interneurons [92, 93]. In the hippocampus, oxidative stress was associated with a decrease in PV-INs as well as a reduction in gamma oscillations [94]. Conversely, in animal models where no change in oxidative stress was observed, PV-positive interneuron number was not changed [92].

The energy requirements of PV-INs also make them highly susceptible to inflammation. For example, the NMDA receptor antagonist ketamine, a pro-inflammatory stimulus, injures PV-INs in vitro and in vivo $[16,95]$. This injury is connected to IL-6mediated Nox2-dependent NADPH oxidase activation and production of superoxide [16, 95]. IL-6 is likely signaling through STAT3 [96]. STAT3 can directly regulate mitochondrial function $[97,98]$, and Nox2 can modulate mitochondrial activity [99-101]. Since PV-INs have many mitochondria, inflammatory stimuli that negatively affect mitochondrial activity and function would negatively affect PV-IN health.

\section{EXCITATORY DRIVE ONTO PARVALBUMIN INTERNEURONS CONTRIBUTES TO THEIR VULNERABILITY}

The strong excitatory drive of PV-INs is mediated by $\mathrm{Ca}^{2+}$-permeable AMPA receptors as well as NMDA receptors [102-104]. While NMDA receptors are the primary source of dendritic $\mathrm{Ca}^{2+}$ in many cell types, in PV-INs dendritic $\mathrm{Ca}^{2+}$ enters through both NMDA receptors and $\mathrm{Ca}^{2+}$-permeable AMPA receptors (Fig. 1) [105]. PVINs have faster $\mathrm{Ca}^{2+}$ influx kinetics than other cell types in part because of $\mathrm{Ca}^{2+}$-permeable AMPA receptors [105]. $\mathrm{Ca}^{2+}$-permeable AMPA receptors are required for long-term potentiation in PV-INs, as excitatory post-synaptic currents are reduced when $\mathrm{Ca}^{2+}$-permeable AMPA receptors are blocked [106, 107].

While $\mathrm{Ca}^{2+}$ homeostasis is an important factor in regulating mitochondrial activity and function, $\mathrm{Ca}^{2+}$-permeable AMPA receptors in PV-INs also lead to vulnerability [108]. Rapid $\mathrm{Ca}^{2+}$ influx through AMPA receptors can lead to a pathological accumulation in the mitochondrial matrix, particularly if PV levels are reduced (Fig. 1b) [109]. If the pathological threshold is crossed, the electron transfer chain is disrupted, reactive oxygen species accumulate, the permeability transition pore opens, the outer mitochondrial membrane ruptures, cytochrome $c$ is released, and an apoptotic cell death program is activated [86, 109]. The combination of large $\mathrm{Ca}^{2+}$ waves, high mitochondrial density, and dependence on uninterrupted ATP supply creates a delicate balance in PV-INs that can rapidly turn into pathology. Even slower, consistent $\mathrm{Ca}^{2+}$ influx through $\mathrm{Ca}^{2+}$-permeable AMPA receptors can be damaging via activation of neuronal nitric oxide synthase and generation of nitric oxide and resultant activation of Poly(ADP-ribose) polymerase 1 (PARP-1), (Fig. 1b), [109, 110]. PARP-1 leads to the release of apoptosis-inducing factor (AIF) via a nuclear signal that proliferates to mitochondria [110].

$\mathrm{Ca}^{2+}$-permeable AMPA receptors are a major entry point of zinc [111-113]. Like $\mathrm{Ca}^{2+}$ influx, zinc influx into neurons leads to the generation of nitric oxide and subsequent activation of PARP-1 and cell death [114]. Zinc is more potent than $\mathrm{Ca}^{2+}$ in its ability to disrupt mitochondrial function [109]. Unlike $\mathrm{Ca}^{2+}$, the influx of zinc through $\mathrm{Ca}^{2+}$-permeable AMPA receptors can lead to a longlasting production of superoxide in mitochondria [112]. At equivalent concentrations, zinc induces a larger increase in cytochrome $c$ and AIF than $\mathrm{Ca}^{2+}[115]$. Consistent with the notion that the presence of $\mathrm{Ca}^{2+}$-permeable AMPA receptors contributes to the vulnerability of PV-INs, blocking of these receptors attenuates cortical neuron death in an in vitro model of traumatic brain injury; attenuates hippocampal pyramidal neuron loss in a mouse hippocampal slice model of oxygen-glucose deprivation; and attenuates retinal ganglion cells loss in a rat model of glaucoma [111, 116, 117].

The majority of PV-INs in humans and monkeys express NMDA receptors $[118,119]$. The ratio of GluN2A-containing NMDA receptors to GluN2B-containing NMDA receptors is five times higher in cultured PV-INs than in pyramidal neurons, and GluN2Acontaining NMDA receptor activity is critical for the preservation of PV immunoreactivity in cultured PV-INs [120]. Importantly, NMDA receptors in PV-INs are regulating gamma rhythms and cognitive behaviors [121].

The dependence of most PV-INs on NMDA receptor function presents another vulnerability. In schizophrenia, NMDA receptors are believed to be hypo-functioning, and the inhibition of NMDA receptors recapitulates many of the symptoms of schizophrenia $[104,122,123]$. NMDA receptor antagonists, such as ketamine and phencyclidine, can transiently reproduce key clinical features of schizophrenia, and are believed to reduce PV-IN excitation [123]. 

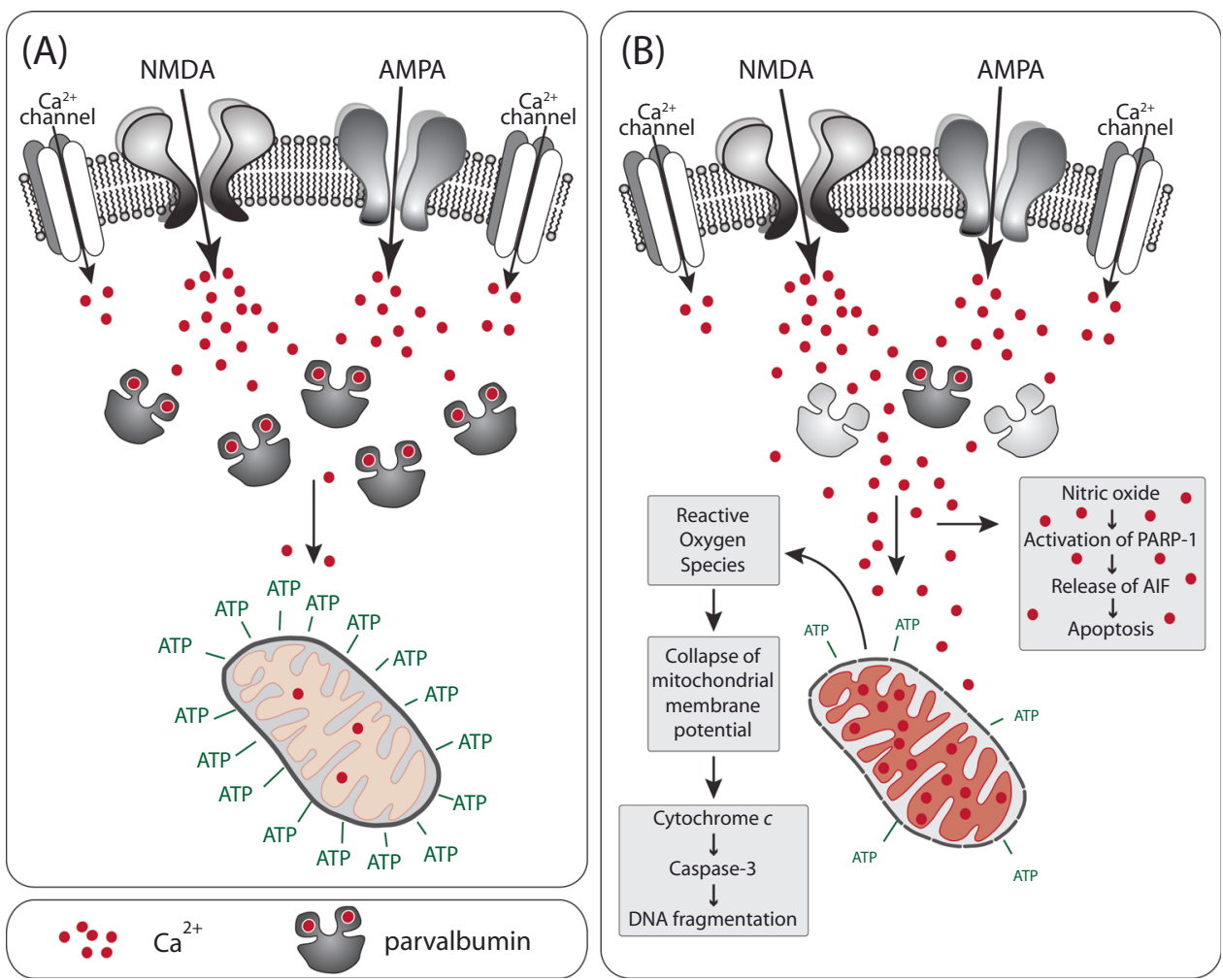

Fig. 1 Parvalbumin protects mitochondria from $\mathrm{Ca}^{2+}$ overload. a Under physiological PV concentrations, $\mathrm{Ca}^{2+}$ entering through receptors and channels will be buffered by PV. $\mathrm{Ca}^{2+}$ in mitochondria remains at physiological levels, promoting ATP production. $\mathbf{b}$ The loss of PV leads to toxic accumulation of $\mathrm{Ca}^{2+}$ in mitochondria. High levels of $\mathrm{Ca}^{2+}$ disrupt the mitochondrial membrane potential and the electron transport chain. The resulting increase in reactive oxygen species causes the collapse of the mitochondrial membrane potential, release of cytochrome $c$, and activation of apoptotic pathways. Moreover, high cytosolic levels of $\mathrm{Ca}^{2+}$ activate neuronal nitric oxide synthase and increase nitric oxide levels. Nitric oxide can initiate another apoptotic pathway.

Working memory is notably impaired in schizophrenia and in other neuro-psychiatric diseases likely due to the expected change in gamma oscillation power resulting from disinhibition [123], in line with transgenic mouse studies in which NMDA receptors are genetically removed in PV-INs [121]. Recent evidence in rats suggests that working memory is dependent on GluN2A-containing NMDA receptors in the prefrontal cortex [124]. Administration of a GluN2A-selective NMDA receptor antagonist caused an abnormal increase in gamma power, while administration of NMDA receptor antagonists that are selective for other subunits resulted in little-to-no change [125]. Human brains from individuals with schizophrenia have a lower density of GluN2Aexpressing PV-INs in layers 3 and 4 of prefrontal cortex compared to the brains from a control group [126]. When this evidence is combined with the finding that gamma oscillations correlate with working memory load in humans, it is likely that the decreases in working memory that are observed in diseases such as schizophrenia are in part mediated by the decrease in glutamatergic inputs through GluN2A-containing NMDA receptors onto PV-INs.

\section{THE DEVELOPMENTAL TRAJECTORY OF INTERNEURONS INTRODUCES UNIQUE VULNERABILITIES}

Like other interneurons, PV-INs are derived from progenitor cells in the embryonic ganglionic eminences of the ventral telencephalon of the developing brain (Fig. 2). Their 'parvalbumin' fate seems to be established at their origin, as the progenitors leave the cell cycle $[127,128]$. Once postmitotic, cells migrate tangentially toward cortical areas and then radially into predetermined cortical layers (Fig. 2, steps 1a, 1b, and 2), [129, 130]. During migration, cellintrinsic programs and external cues must be coordinated in a time- and location-sensitive manner [131]. Externally, an exquisite coordination of attractant and repellant guidance factors transmitted from various brain regions guide migrating neurons to their ultimate destination [132]. Intracellularly, an expression of responsive receptors on the neurons must be timed with the transmission of guidance factors from remote brain tissues. These receptors activate intraneuronal signaling cascades that dynamically remodel microtubule and actin cytoskeletal components to extend and retract processes that move the cells toward their destination [133]. As interneurons assume their final position within a specific region and layer of the cortex and hippocampus, they have to switch to a molecular program designed to establish axon pathfinding and synaptic connections with local excitatory neurons born in the subventricular zone, and with other interneurons that had migrated from areas deep inside the developing brain (Fig. 2, steps 3 and 4), [129, 130]. PV-INs colonize the cortex in an insideout fashion, by which layers $\mathrm{VI} / \mathrm{V}$ are colonized first, followed by layers IV, III, and II [134].

Migration of interneurons and incorporation into the local environment constitute times of high vulnerability. During mouse brain development, the fraction of GABAergic interneurons to glutamatergic neurons is constant from early corticogenesis throughout brain development and into the adult brain [135]. Any disruption during migration cannot only leave interneurons in the wrong location, as has been shown in schizophrenia [136138], but also have permanent consequences on the ratio of specific neuron types. The characteristics of the large number of interneuron types with diverse transcriptional signatures are not random but rather predetermined at the earliest developmental stages $[127,128,130]$. Such an early determination of fate would limit their ability for self-renewal or de-differentiation if damaged during migration. The hippocampus is the farthest brain area reached by interneurons, and as such has the longest 


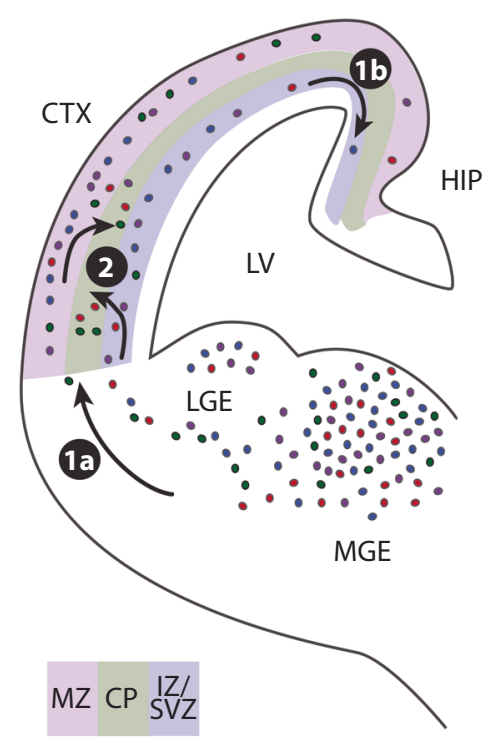

4

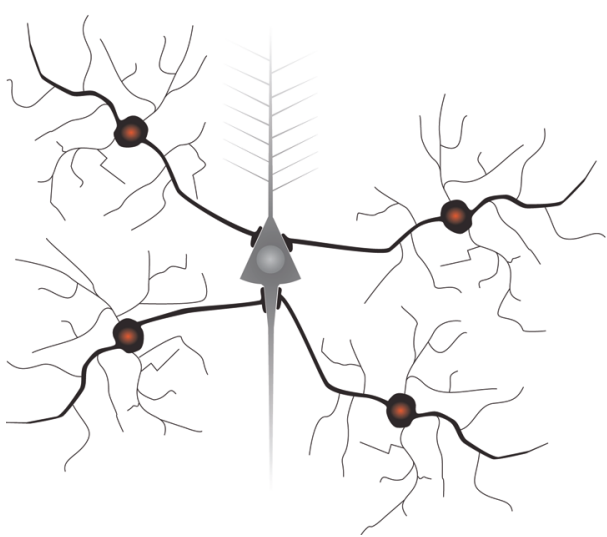

3

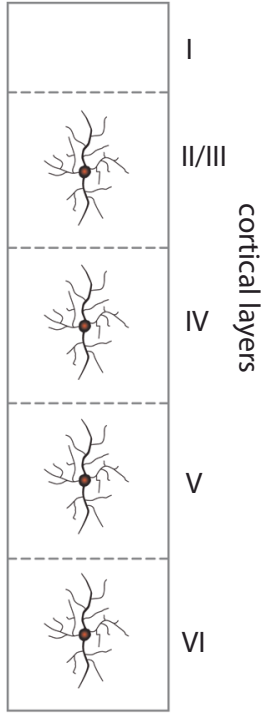

(3)
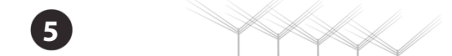

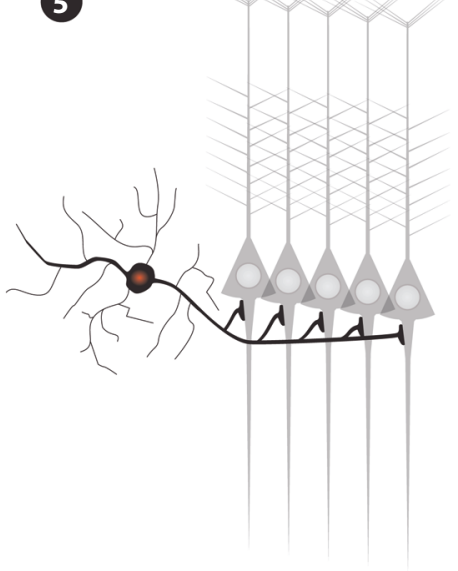

Fig. 2 Development of cortical interneurons. The majority of interneurons are derived in the medial and lateral ganglionic eminence (MGE; LGE) from where they migrate tangentially along the marginal zone (MZ) and intermediate zone (IZ)/subventricular zone (SVZ) of the developing cortex, (1a). Most PV-INs are derived from the ventral MGE, and their 'parvalbumin' fate seems to be established at their origin, as the progenitors leave the cell cycle. Interneurons migrate through the cortex in a lateral-to-medial tangent, with the hippocampus among the last areas to be settled (1b). To enter the developing cortical plate (CP), interneurons have to switch their mode of migration from tangential to radial (2). PV-INs colonize the cortex in an inside-out fashion, by which layers VI/V are colonized first, followed by layers IV, III, and II. In the adult brain, parvalbumin interneurons are found in all cortical layers except layer I (3), and in the hippocampal pyramidal layer. As the final step, interneurons have to build synaptic networks with pyramidal neurons and other interneurons (4). Parvalbumin neurons synapse onto pyramidal neurons at the cell body and the axon hillock, and thus exert control over information outflow. Network activity is synchronized by individual interneurons contacting nearly every local pyramidal neuron (5). LV lateral ventricle; CTX cortex, HIP hippocampus.

developmentally open window, with the highest likelihood to be affected by deleterious impacts on migration [139]. The preponderance of interneuron pathologies in the hippocampus and adjacent cortical areas, such as the interneuron pathologies observed in schizophrenia and BPD, might be, at least in part, a reflection of this extended developmental vulnerability $[1,9,122,140-142]$

Taken together, for cells to find their proper location and integrate into the local neuronal network, intrinsic programs that determine interneuron cell-type, timing, and response to guidance factors, cytoskeletal reorganization, migration, and connection to synaptic partners, have to be coordinated with external cues, which themselves are subject to intrinsic programs in distant cell types. It seems almost beyond a miracle of nature for this process to work correctly, and yet in most cases it succeeds. While there likely is some space to correct for minor variabilities, it seems reasonable to assume that the process also has some vulnerabilities.

\section{CONCLUSION AND FUTURE DIRECTIONS}

PV-INs are important for proper brain function. Their ontogeny and physiological properties render them uniquely susceptible to environmental disturbances. This vulnerability contributes to their role in numerous brain disorders. PV-INs are implicated in neurodevelopmental diseases such as early-onset psychiatric disorders and in neurodegenerative diseases such as $A D$, demonstrating the vulnerability of this interneuron subset throughout life. Therapeutic strategies to protect PV-INs from injury should be explored to prevent and/or lessen their role in the various brain disorders in which dysfunctional PV-INs are implicated. For example, recently discovered GluN2A-selective 
NMDA receptor positive allosteric modulators could help to restore normal gamma oscillations and improve working memory in patients with schizophrenia, as these compounds should selectively target PV-INs [143, 144].

New approaches should also be explored to better understand PV-IN vulnerability. Human PV-INs can be derived from induced pluripotent stem cells to examine metabolism, genetics, physiology, and responses to stress. Novel mouse models, including models that label PV-INs with tdTomato such as [145], can be exposed to various conditions to differentiate between loss of neurons and loss of PV expression. Imaging modalities, including functional magnetic resonance imaging, can be used to observe the integrity of PV-IN-containing circuits in forebrain and hippocampus in humans with disease compared to healthy controls. We will soon have a greater understanding of PV-IN vulnerability because of the novel tools at our disposal.

\section{FUNDING AND DISCLOSURE}

This work is supported by MH064913 (JBR), AG033679 (LLD), AG058856 (LLD), VA Tennessee Valley Geriatric Research, Education and Clinical Center (GRECC) (LLD), and Vanderbilt Institute for Clinical and Translational Research (LLD). The authors have nothing to disclose.

\section{AUTHOR CONTRIBUTIONS}

JBR and CK were involved in writing the manuscript, CK and LLD were involved in editing the manuscript.

\section{ADDITIONAL INFORMATION}

Publisher's note Springer Nature remains neutral with regard to jurisdictional claims in published maps and institutional affiliations.

\section{REFERENCES}

1. Konradi C, Yang CK, Zimmerman El, Lohmann KM, Gresch P, Pantazopoulos H, et al. Hippocampal interneurons are abnormal in schizophrenia. Schizophr Res. 2011;131:165-73.

2. Lewis DA, Curley AA, Glausier JR, Volk DW. Cortical parvalbumin interneurons and cognitive dysfunction in schizophrenia. Trends Neurosci. 2012;35:57-67.

3. Marin O. Interneuron dysfunction in psychiatric disorders. Nat Rev Neurosci. 2012;13:107-20.

4. Gonzalez-Burgos G, Cho RY, Lewis DA. Alterations in cortical network oscillations and parvalbumin neurons in schizophrenia. Biol Psychiatry. 2015;77:1031-40.

5. Mukherjee A, Carvalho F, Eliez S, Caroni P. Long-lasting rescue of network and cognitive dysfunction in a genetic schizophrenia model. Cell. 2019;178: 1387-402 e14.

6. Lodge DJ, Behrens MM, Grace AA. A loss of parvalbumin-containing interneurons is associated with diminished oscillatory activity in an animal model of schizophrenia. J Neurosci. 2009:29:2344-54.

7. Gill KM, Grace AA. Corresponding decrease in neuronal markers signals progressive parvalbumin neuron loss in MAM schizophrenia model. Int J Neuropsychopharmacol. 2014;17:1609-19.

8. Fachim HA, Srisawat U, Dalton CF, Reynolds GP. Parvalbumin promoter hypermethylation in postmortem brain in schizophrenia. Epigenomics. 2018;10:519-24.

9. Wang AY, Lohmann KM, Yang CK, Zimmerman El, Pantazopoulos $\mathrm{H}$, Herring $\mathrm{N}$, et al. Bipolar disorder type 1 and schizophrenia are accompanied by decreased density of parvalbumin- and somatostatin-positive interneurons in the parahippocampal region. Acta Neuropathol. 2011;122:615-26.

10. Chung DW, Volk DW, Arion D, Zhang Y, Sampson AR, Lewis DA. Dysregulated ErbB4 splicing in schizophrenia: selective effects on parvalbumin expression. Am J Psychiatry. 2016;173:60-8.

11. Volk DW, Matsubara T, Li S, Sengupta EJ, Georgiev D, Minabe Y, et al. Deficits in transcriptional regulators of cortical parvalbumin neurons in schizophrenia. Am J Psychiatry. 2012;169:1082-91.

12. Chung DW, Fish KN, Lewis DA. Pathological basis for deficient excitatory drive to cortical parvalbumin interneurons in schizophrenia. Am J Psychiatry. 2016;173: $1131-9$.
13. Barr MS, Farzan F, Tran LC, Chen R, Fitzgerald PB, Daskalakis ZJ. Evidence for excessive frontal evoked gamma oscillatory activity in schizophrenia during working memory. Schizophr Res. 2010;121:146-52.

14. Koh MT, Shao Y, Sherwood A, Smith DR. Impaired hippocampal-dependent memory and reduced parvalbumin-positive interneurons in a ketamine mouse model of schizophrenia. Schizophr Res. 2016;171:187-94.

15. Harrington AJ, Raissi A, Rajkovich K, Berto S, Kumar J, Molinaro G, et al. MEF2C regulates cortical inhibitory and excitatory synapses and behaviors relevant to neurodevelopmental disorders. eLife 2016;5:e20059.

16. Behrens MM, Ali SS, Dao DN, Lucero J, Shekhtman G, Quick KL, et al. Ketamineinduced loss of phenotype of fast-spiking interneurons is mediated by NADPHoxidase. Science. 2007;318:1645-7.

17. Du Y, Grace AA. Loss of parvalbumin in the hippocampus of MAM schizophrenia model rats is attenuated by peripubertal diazepam. Int J Neuropsychopharmacol. 2016;19:pyw060.

18. Powell SB, Sejnowski TJ, Behrens MM. Behavioral and neurochemical consequences of cortical oxidative stress on parvalbumin-interneuron maturation in rodent models of schizophrenia. Neuropharmacology. 2012;62:1322-31.

19. Enwright JF, Sanapala S, Foglio A, Berry R, Fish KN, Lewis DA. Reduced labeling of parvalbumin neurons and perineuronal nets in the dorsolateral prefrontal cortex of subjects with schizophrenia. Neuropsychopharmacology. 2016;41:2206-14.

20. Filice F, Vorckel KJ, Sungur AO, Wohr M, Schwaller B. Reduction in parvalbumin expression not loss of the parvalbumin-expressing GABA interneuron subpopulation in genetic parvalbumin and shank mouse models of autism. Mol Brain. 2016;9:10.

21. laccarino HF, Singer AC, Martorell AJ, Rudenko A, Gao F, Gillingham TZ, et al. Gamma frequency entrainment attenuates amyloid load and modifies microglia. Nature. 2016;540:230-5.

22. Rubio SE, Vega-Flores G, Martinez A, Bosch C, Perez-Mediavilla A, del Rio J, et al. Accelerated aging of the GABAergic septohippocampal pathway and decreased hippocampal rhythms in a mouse model of Alzheimer's disease. FASEB J. 2012;26:4458-67.

23. Ahnaou A, Moechars D, Raeymaekers L, Biermans R, Manyakov NV, Bottelbergs $A$, et al. Emergence of early alterations in network oscillations and functional connectivity in a tau seeding mouse model of Alzheimer's disease pathology. Sci Rep. 2017;7:14189.

24. Ogiwara I, Miyamoto H, Morita N, Atapour N, Mazaki E, Inoue I, et al. Nav1.1 localizes to axons of parvalbumin-positive inhibitory interneurons: a circuit basis for epileptic seizures in mice carrying an Scn1a gene mutation. J Neurosci. 2007:27:5903-14.

25. Wang W, Takashima S, Segawa Y, Itoh M, Shi X, Hwang SK, et al. The developmental changes of $\mathrm{Na}(\mathrm{V}) 1.1$ and $\mathrm{Na}(\mathrm{v}) 1.2$ expression in the human hippocampus and temporal lobe. Brain Res. 2011;1389:61-70.

26. Verret L, Mann EO, Hang GB, Barth AM, Cobos I, Ho K, et al. Inhibitory interneuron deficit links altered network activity and cognitive dysfunction in Alzheimer model. Cell. 2012;149:708-21.

27. Nair J, Klaassen AL, Arato J, Vyssotski AL, Harvey M, Rainer G. Basal forebrain contributes to default mode network regulation. Proc Natl Acad Sci USA. 2018;115:1352-7.

28. Jones DT, Machulda MM, Vemuri P, McDade EM, Zeng G, Senjem ML, et al. Agerelated changes in the default mode network are more advanced in Alzheimer disease. Neurology. 2011;77:1524-31.

29. Zhang HY, Wang SJ, Liu B, Ma ZL, Yang M, Zhang ZJ, et al. Resting brain connectivity: changes during the progress of Alzheimer disease. Radiology. 2010;256:598-606.

30. Zhou J, Greicius MD, Gennatas ED, Growdon ME, Jang JY, Rabinovici GD, et al. Divergent network connectivity changes in behavioural variant frontotemporal dementia and Alzheimer's disease. Brain. 2010;133:1352-67.

31. Cha J, Jo HJ, Kim HJ, Seo SW, Kim HS, Yoon U, et al. Functional alteration patterns of default mode networks: comparisons of normal aging, amnestic mild cognitive impairment and Alzheimer's disease. Eur J Neurosci. 2013;37:1916-24.

32. Greicius MD, Srivastava G, Reiss AL, Menon V. Default-mode network activity distinguishes Alzheimer's disease from healthy aging: evidence from functional MRI. Proc Natl Acad Sci USA. 2004;101:4637-42.

33. Mahar I, Albuquerque MS, Mondragon-Rodriguez S, Cavanagh C, Davoli MA, Chabot JG, et al. Phenotypic alterations in hippocampal NPY- and PV-expressing interneurons in a presymptomatic transgenic mouse model of Alzheimer's disease. Front Aging Neurosci. 2016;8:327.

34. Takahashi H, Brasnjevic I, Rutten BP, Van Der Kolk N, Perl DP, Bouras C, et al. Hippocampal interneuron loss in an APP/PS1 double mutant mouse and in Alzheimer's disease. Brain Struct Funct. 2010;214:145-60.

35. Verdaguer $\mathrm{E}$, Brox S, Petrov $\mathrm{D}$, Olloquequi J, Romero $\mathrm{R}$, de Lemos $\mathrm{ML}$, et al. Vulnerability of calbindin, calretinin and parvalbumin in a transgenic/knock-in APPswe/PS1dE9 mouse model of Alzheimer disease together with disruption of hippocampal neurogenesis. Exp Gerontol. 2015;69:176-88. 
36. Albuquerque MS, Mahar I, Davoli MA, Chabot JG, Mechawar N, Quirion R, et al. Regional and sub-regional differences in hippocampal GABAergic neuronal vulnerability in the TgCRND8 mouse model of Alzheimer's disease. Front Aging Neurosci. 2015;7:30.

37. Baig S, Wilcock GK, Love S. Loss of perineuronal net $\mathrm{N}$-acetylgalactosamine in Alzheimer's disease. Acta Neuropathol. 2005;110:393-401.

38. Saiz-Sanchez D, De la Rosa-Prieto C, Ubeda-Banon I, Martinez-Marcos A. Interneurons, tau and amyloid-beta in the piriform cortex in Alzheimer's disease. Brain Struct Funct. 2015;220:2011-25.

39. De Crescenzo F, Postorino V, Siracusano M, Riccioni A, Armando M, Curatolo $P$, et al. Autistic symptoms in schizophrenia spectrum disorders: a systematic review and meta-analysis. Front Psychiatry. 2019;10:78.

40. Hamm JP, Peterka DS, Gogos JA, Yuste R. Altered cortical ensembles in mouse models of schizophrenia. Neuron. 2017;94:153-67 e8.

41. Piskorowski RA, Nasrallah K, Diamantopoulou A, Mukai J, Hassan SI, Siegelbaum $\mathrm{SA}$, et al. Age-dependent specific changes in area CA2 of the hippocampus and social memory deficit in a mouse model of the 22q11.2 deletion syndrome. Neuron. 2016;89:163-76.

42. Murphy KC, Jones LA, Owen MJ. High rates of schizophrenia in adults with velocardio-facial syndrome. Arch Gen Psychiatry. 1999;56:940-5.

43. Stark KL, Xu B, Bagchi A, Lai WS, Liu H, Hsu R, et al. Altered brain microRNA biogenesis contributes to phenotypic deficits in a 22q11-deletion mouse model. Nat Genet. 2008;40:751-60.

44. Penagarikano O, Abrahams BS, Herman El, Winden KD, Gdalyahu A, Dong $\mathrm{H}$ et al. Absence of CNTNAP2 leads to epilepsy, neuronal migration abnormalities, and core autism-related deficits. Cell. 2011;147:235-46.

45. Lauber E, Filice F, Schwaller B. Dysregulation of parvalbumin expression in the Cntnap2 $2^{-1-}$ mouse model of autism spectrum disorder. Front Mol Neurosci. 2018;11:262.

46. Selimbeyoglu A, Kim CK, Inoue M, Lee SY, Hong ASO, Kauvar I, et al. Modulation of prefrontal cortex excitation/inhibition balance rescues social behavior in CNTNAP2-deficient mice. Sci Transl Med. 2017;9:eaah6733.

47. Chen LY, Jiang M, Zhang B, Gokce O, Sudhof TC. Conditional deletion of all neurexins defines diversity of essential synaptic organizer functions for neurexins. Neuron. 2017;94:611-25 e4.

48. Mao W, Watanabe T, Cho S, Frost JL, Truong T, Zhao X, et al. Shank1 regulates excitatory synaptic transmission in mouse hippocampal parvalbuminexpressing inhibitory interneurons. Eur J Neurosci. 2015;41:1025-35.

49. Berkel S, Marshall CR, Weiss B, Howe J, Roeth R, Moog U, et al. Mutations in the SHANK2 synaptic scaffolding gene in autism spectrum disorder and mental retardation. Nat Genet. 2010;42:489-91.

50. Shcheglovitov A, Shcheglovitova O, Yazawa M, Portmann T, Shu R, Sebastiano V, et al. SHANK3 and IGF1 restore synaptic deficits in neurons from 22q13 deletion syndrome patients. Nature. 2013;503:267-71.

51. Nguyen PT, Nakamura T, Hori E, Urakawa S, Uwano T, Zhao J, et al. Cognitive and socio-emotional deficits in platelet-derived growth factor receptor-beta gene knockout mice. PLoS ONE. 2011;6:e18004.

52. Nakamura T, Matsumoto J, Takamura $Y$, Ishii $Y$, Sasahara M, Ono T, et al. Relationships among parvalbumin-immunoreactive neuron density, phase-locked gamma oscillations, and autistic/schizophrenic symptoms in PDGFR-beta knockout and control mice. PLoS ONE. 2015;10:e0119258.

53. Wohr M, Orduz D, Gregory P, Moreno H, Khan U, Vorckel KJ, et al. Lack of parvalbumin in mice leads to behavioral deficits relevant to all human autism core symptoms and related neural morphofunctional abnormalities. Transl Psychiatry. 2015;5:e525.

54. Chao HT, Chen H, Samaco RC, Xue M, Chahrour M, Yoo J, et al. Dysfunction in GABA signalling mediates autism-like stereotypies and Rett syndrome phenotypes. Nature. 2010;468:263-9.

55. Consortium C-DGotPG, Lee SH, Ripke S, Neale BM, Faraone SV, Purcell SM, et al. Genetic relationship between five psychiatric disorders estimated from genome-wide SNPs. Nat Genet. 2013;45:984-94.

56. Cardno AG, Rijsdijk FV, Sham PC, Murray RM, McGuffin P. A twin study of genetic relationships between psychotic symptoms. Am J Psychiatry. 2002;159:539-45.

57. Lee FH, Zai CC, Cordes SP, Roder JC, Wong AH. Abnormal interneuron development in disrupted-in-schizophrenia-1 L100P mutant mice. Mol Brain. 2013;6:20.

58. Clapcote SJ, Lipina TV, Millar JK, Mackie S, Christie S, Ogawa F, et al. Behavioral phenotypes of Disc1 missense mutations in mice. Neuron. 2007;54:387-402.

59. Delevich K, Jaaro-Peled H, Penzo M, Sawa A, Li B. Parvalbumin interneuron dysfunction in a thalamo-prefrontal cortical circuit in disc1 locus impairment mice. eNeuro. 2020;7:ENEURO.0496-19.2020.

60. Jaaro-Peled H, Kumar S, Hughes D, Kim S-H, Zoubovsky S, Hirota-Tsuyada $Y$, et al. The cortico-striatal circuit regulates sensorimotor gating via Disc1/Huntingtin-mediated Bdnf transport. 2018. https://www.biorxiv.org/content/ 10.1101/497446v1.full.
61. Shen S, Lang B, Nakamoto C, Zhang F, Pu J, Kuan SL, et al. Schizophrenia-related neural and behavioral phenotypes in transgenic mice expressing truncated Disc1. J Neurosci. 2008;28:10893-904.

62. Jones NC, Hudson M, Foreman J, Rind G, Hill R, Manning EE, et al. Brain-derived neurotrophic factor haploinsufficiency impairs high-frequency cortical oscillations in mice. Eur J Neurosci. 2018;48:2816-25.

63. Sloviter RS, Sollas AL, Barbaro NM, Laxer KD. Calcium-binding protein (calbindinD28K) and parvalbumin immunocytochemistry in the normal and epileptic human hippocampus. J Comp Neurol. 1991;308:381-96.

64. Garbelli R, Meroni A, Magnaghi G, Beolchi MS, Ferrario A, Tassi L, et al. Architectural (Type IA) focal cortical dysplasia and parvalbumin immunostaining in temporal lobe epilepsy. Epilepsia. 2006;47:1074-8.

65. Guentchev M, Hainfellner JA, Trabattoni GR, Budka $H$. Distribution of parvalbumin-immunoreactive neurons in brain correlates with hippocampal and temporal cortical pathology in Creutzfeldt-Jakob disease. J Neuropathol Exp Neurol. 1997;56:1119-24.

66. Hu H, Gan J, Jonas P. Interneurons. Fast-spiking, parvalbumin(+) GABAergic interneurons: from cellular design to microcircuit function. Science. 2014;345: 1255263.

67. Caillard O, Moreno H, Schwaller B, Llano I, Celio MR, Marty A. Role of the calcium-binding protein parvalbumin in short-term synaptic plasticity. Proc Natl Acad Sci USA. 2000;97:13372-7.

68. Wahr PA, Michele DE, Metzger JM. Parvalbumin gene transfer corrects diastolic dysfunction in diseased cardiac myocytes. Proc Natl Acad Sci USA. 1999;96: 11982-5.

69. Galarreta M, Hestrin S. Electrical and chemical synapses among parvalbumin fast-spiking GABAergic interneurons in adult mouse neocortex. Proc Natl Acad Sci USA. 2002;99:12438-43.

70. Donato F, Rompani SB, Caroni P. Parvalbumin-expressing basket-cell network plasticity induced by experience regulates adult learning. Nature. 2013;504: 272-6.

71. Yazaki-Sugiyama Y, Kang S, Cateau H, Fukai T, Hensch TK. Bidirectional plasticity in fast-spiking GABA circuits by visual experience. Nature. 2009;462: 218-21.

72. Kuhlman SJ, Olivas ND, Tring E, Ikrar T, Xu X, Trachtenberg JT. A disinhibitory microcircuit initiates critical-period plasticity in the visual cortex. Nature. 2013;501:543-6.

73. Kaplan ES, Cooke SF, Komorowski RW, Chubykin AA, Thomazeau A, Khibnik LA, et al. Contrasting roles for parvalbumin-expressing inhibitory neurons in two forms of adult visual cortical plasticity. Elife. 2016;5:e11450.

74. Packer AM, Yuste R. Dense, unspecific connectivity of neocortical parvalbuminpositive interneurons: a canonical microcircuit for inhibition? J Neurosci. 2011;31:13260-71

75. Buzsaki G, Wang XJ. Mechanisms of gamma oscillations. Annu Rev Neurosci. 2012;35:203-25.

76. Cardin JA, Carlen M, Meletis K, Knoblich U, Zhang F, Deisseroth K, et al. Driving fast-spiking cells induces gamma rhythm and controls sensory responses. Nature. 2009;459:663-7.

77. Sohal VS, Zhang F, Yizhar O, Deisseroth K. Parvalbumin neurons and gamma rhythms enhance cortical circuit performance. Nature. 2009;459:698-702.

78. Volman V, Behrens MM, Sejnowski TJ. Downregulation of parvalbumin at cortical GABA synapses reduces network gamma oscillatory activity. J Neurosci. 2011:31:18137-48

79. Howard MW, Rizzuto DS, Caplan JB, Madsen JR, Lisman J, AschenbrennerScheibe R, et al. Gamma oscillations correlate with working memory load in humans. Cereb Cortex. 2003;13:1369-74.

80. Gulyas Al, Megias M, Emri Z, Freund TF. Total number and ratio of excitatory and inhibitory synapses converging onto single interneurons of different types in the CA1 area of the rat hippocampus. J Neurosci. 1999;19:10082-97.

81. Kann O, Papageorgiou IE, Draguhn A. Highly energized inhibitory interneurons are a central element for information processing in cortical networks. J Cereb Blood Flow Metab. 2014;34:1270-82.

82. Inan M, Zhao M, Manuszak M, Karakaya C, Rajadhyaksha AM, Pickel VM, et al. Energy deficit in parvalbumin neurons leads to circuit dysfunction, impaired sensory gating and social disability. Neurobiol Dis. 2016;93:35-46.

83. Kann O, Huchzermeyer C, Kovacs R, Wirtz S, Schuelke M. Gamma oscillations in the hippocampus require high complex I gene expression and strong functional performance of mitochondria. Brain. 2011;134:345-58.

84. Huchzermeyer C, Berndt N, Holzhutter HG, Kann O. Oxygen consumption rates during three different neuronal activity states in the hippocampal CA3 network. J Cereb Blood Flow Metab. 2013;33:263-71.

85. Gulyas Al, Buzsaki G, Freund TF, Hirase H. Populations of hippocampal inhibitory neurons express different levels of cytochrome c. Eur J Neurosci. 2006;23:2581-94.

86. Liu X, Kim CN, Yang J, Jemmerson R, Wang X. Induction of apoptotic program in cell-free extracts: requirement for dATP and cytochrome c. Cell. 1996;86:147-57. 
87. Kisvarday ZF, Beaulieu C, Eysel UT. Network of GABAergic large basket cells in cat visual cortex (area 18): implication for lateral disinhibition. J Comp Neurol. 1993;327:398-415.

88. Sik A, Penttonen M, Ylinen A, Buzsaki G. Hippocampal CA1 interneurons: an in vivo intracellular labeling study. J Neurosci. 1995;15:6651-65.

89. Buhl EH, Halasy K, Somogyi P. Diverse sources of hippocampal unitary inhibitory postsynaptic potentials and the number of synaptic release sites. Nature. 1994;368:823-8.

90. Tremblay R, Lee S, Rudy B. GABAergic interneurons in the neocortex: from cellular properties to circuits. Neuron. 2016;91:260-92.

91. Whittaker RG, Turnbull DM, Whittington MA, Cunningham MO. Impaired mitochondrial function abolishes gamma oscillations in the hippocampus through an effect on fast-spiking interneurons. Brain. 2011;134:e180. author reply e81

92. Steullet P, Cabungcal JH, Coyle J, Didriksen M, Gill K, Grace AA, et al. Oxidative stress-driven parvalbumin interneuron impairment as a common mechanism in models of schizophrenia. Mol Psychiatry. 2017.

93. Cabungcal JH, Nicolas D, Kraftsik R, Cuenod M, Do KQ, Hornung JP. Glutathione deficit during development induces anomalies in the rat anterior cingulate GABAergic neurons: relevance to schizophrenia. Neurobiol Dis. 2006;22:624-37.

94. Steullet P, Cabungcal JH, Kulak A, Kraftsik R, Chen Y, Dalton TP, et al. Redox dysregulation affects the ventral but not dorsal hippocampus: impairment of parvalbumin neurons, gamma oscillations, and related behaviors. J Neurosci. 2010;30:2547-58

95. Behrens MM, Ali SS, Dugan LL. Interleukin-6 mediates the increase in NADPHoxidase in the ketamine model of schizophrenia. J Neurosci. 2008;28:13957-66.

96. Dugan LL, Ali SS, Shekhtman G, Roberts AJ, Lucero J, Quick KL, et al. IL-6 mediated degeneration of forebrain GABAergic interneurons and cognitive impairment in aged mice through activation of neuronal NADPH oxidase. PLoS ONE. 2009;4:e5518.

97. Gough DJ, Corlett A, Schlessinger K, Wegrzyn J, Larner AC, Levy DE. Mitochondrial STAT3 supports Ras-dependent oncogenic transformation. Science. 2009;324:1713-6.

98. Wegrzyn J, Potla R, Chwae YJ, Sepuri NB, Zhang Q, Koeck T, et al. Function of mitochondrial Stat3 in cellular respiration. Science. 2009;323:793-7.

99. Kim YM, Kim SJ, Tatsunami R, Yamamura H, Fukai T, Ushio-Fukai M. ROS-induced ROS release orchestrated by Nox4, Nox2, and mitochondria in VEGF signaling and angiogenesis. Am J Physiol Cell Physiol. 2017;312:C749-64.

100. Joseph LC, Barca E, Subramanyam P, Komrowski M, Pajvani U, Colecraft HM, et al. Inhibition of NAPDH oxidase 2 (NOX2) prevents oxidative stress and mitochondrial abnormalities caused by saturated fat in cardiomyocytes. PLoS ONE. 2016;11:e0145750.

101. Dikalov SI, Nazarewicz RR, Bikineyeva A, Hilenski L, Lassegue B, Griendling KK, et al. Nox2-induced production of mitochondrial superoxide in angiotensin IImediated endothelial oxidative stress and hypertension. Antioxid Redox Signal. 2014;20:281-94.

102. Lu J, Tucciarone J, Lin Y, Huang ZJ. Input-specific maturation of synaptic dynamics of parvalbumin interneurons in primary visual cortex. Proc Natl Acad Sci USA. 2014;111:16895-900.

103. Fuchs EC, Zivkovic AR, Cunningham MO, Middleton S, Lebeau FE, Bannerman $\mathrm{DM}$, et al. Recruitment of parvalbumin-positive interneurons determines hippocampal function and associated behavior. Neuron. 2007;53:591-604.

104. Timofeeva OA, Levin ED. Glutamate and nicotinic receptor interactions in working memory: importance for the cognitive impairment of schizophrenia. Neuroscience. 2011;195:21-36.

105. Goldberg JH, Yuste R, Tamas G. Ca2+ imaging of mouse neocortical interneurone dendrites: contribution of Ca2+-permeable AMPA and NMDA receptors to subthreshold Ca2+dynamics. J Physiol. 2003:551:67-78.

106. Szabo A, Somogyi J, Cauli B, Lambolez B, Somogyi P, Lamsa KP. Calciumpermeable AMPA receptors provide a common mechanism for LTP in glutamatergic synapses of distinct hippocampal interneuron types. J Neurosci. 2012;32:6511-6.

107. Nissen W, Szabo A, Somogyi J, Somogyi P, Lamsa KP. Cell type-specific longterm plasticity at glutamatergic synapses onto hippocampal interneurons expressing either parvalbumin or CB1 cannabinoid receptor. J Neurosci. 2010;30:1337-47.

108. Contreras L, Drago I, Zampese E, Pozzan T. Mitochondria: the calcium connection. Biochim Biophys Acta. 2010;1797:607-18.

109. Kwak S, Weiss JH. Calcium-permeable AMPA channels in neurodegenerative disease and ischemia. Curr Opin Neurobiol. 2006;16:281-7.

110. Hong SJ, Dawson TM, Dawson VL. Nuclear and mitochondrial conversations in cell death: PARP-1 and AIF signaling. Trends Pharmacol Sci. 2004;25:259-64.

111. Yin HZ, Sensi SL, Ogoshi F, Weiss JH. Blockade of Ca2+-permeable AMPA/ kainate channels decreases oxygen-glucose deprivation-induced Zn2+ accumulation and neuronal loss in hippocampal pyramidal neurons. J Neurosci. 2002;22:1273-9.
112. Sensi SL, Yin HZ, Carriedo SG, Rao SS, Weiss JH. Preferential Zn2+ influx through Ca2+-permeable AMPA/kainate channels triggers prolonged mitochondrial superoxide production. Proc Natl Acad Sci USA. 1999;96:2414-9.

113. Jia Y, Jeng JM, Sensi SL, Weiss JH. Zn2+ currents are mediated by calciumpermeable AMPA/kainate channels in cultured murine hippocampal neurones. J Physiol. 2002;543:35-48.

114. Kim YH, Koh JY. The role of NADPH oxidase and neuronal nitric oxide synthase in zinc-induced poly(ADP-ribose) polymerase activation and cell death in cortical culture. Exp Neurol. 2002;177:407-18.

115. Jiang D, Sullivan PG, Sensi SL, Steward O, Weiss JH. Zn(2+) induces permeability transition pore opening and release of pro-apoptotic peptides from neuronal mitochondria. J Biol Chem. 2001;276:47524-9.

116. Cueva Vargas JL, Osswald IK, Unsain N, Aurousseau MR, Barker PA, Bowie D, et al. Soluble tumor necrosis factor alpha promotes retinal ganglion cell death in glaucoma via calcium-permeable AMPA receptor activation. J Neurosci. 2015;35:12088-102.

117. Spaethling JM, Klein DM, Singh $P$, Meaney DF. Calcium-permeable AMPA receptors appear in cortical neurons after traumatic mechanical injury and contribute to neuronal fate. J Neurotrauma. 2008;25:1207-16.

118. Huntley GW, Vickers JC, Morrison JH. Quantitative localization of NMDAR1 receptor subunit immunoreactivity in inferotemporal and prefrontal association cortices of monkey and human. Brain Res. 1997;749:245-62.

119. Huntley GW, Vickers JC, Janssen W, Brose N, Heinemann SF, Morrison JH. Distribution and synaptic localization of immunocytochemically identified NMDA receptor subunit proteins in sensory-motor and visual cortices of monkey and human. J Neurosci. 1994;14:3603-19.

120. Kinney JW, Davis CN, Tabarean I, Conti B, Bartfai T, Behrens MM. A specific role for NR2A-containing NMDA receptors in the maintenance of parvalbumin and GAD67 immunoreactivity in cultured interneurons. J Neurosci. 2006;26: 1604-15.

121. Carlen M, Meletis K, Siegle JH, Cardin JA, Futai K, Vierling-Claassen D, et al. A critical role for NMDA receptors in parvalbumin interneurons for gamma rhythm induction and behavior. Mol Psychiatry. 2012;17:537-48.

122. Konradi C, Heckers S. Molecular aspects of glutamate dysregulation: implications for schizophrenia and its treatment. Pharm Ther. 2003;97:153-79.

123. Lisman JE, Coyle JT, Green RW, Javitt DC, Benes FM, Heckers S, et al. Circuitbased framework for understanding neurotransmitter and risk gene interactions in schizophrenia. Trends Neurosci. 2008;31:234-42.

124. McQuail JA, Beas BS, Kelly KB, Simpson KL, Frazier CJ, Setlow B, et al. NR2Acontaining NMDARs in the prefrontal cortex are required for working memory and associated with age-related cognitive decline. J Neurosci. 2016;36:12537-48.

125. Kocsis B. Differential role of NR2A and NR2B subunits in N-methyl-D-aspartate receptor antagonist-induced aberrant cortical gamma oscillations. Biol Psychiatry. 2012;71:987-95.

126. Bitanihirwe BK, Lim MP, Kelley JF, Kaneko T, Woo TU. Glutamatergic deficits and parvalbumin-containing inhibitory neurons in the prefrontal cortex in schizophrenia. BMC Psychiatry. 2009;9:71.

127. Wonders $\mathrm{CP}$, Anderson SA. The origin and specification of cortical interneurons. Nat Rev Neurosci. 2006;7:687-96.

128. Bandler RC, Mayer C, Fishell G. Cortical interneuron specification: the juncture of genes, time and geometry. Curr Opin Neurobiol. 2017;42:17-24.

129. Hu JS, Vogt D, Sandberg M, Rubenstein JL. Cortical interneuron development: a tale of time and space. Development. 2017;144:3867-78.

130. Lim L, Mi D, Llorca A, Marin O. Development and functional diversification of cortical interneurons. Neuron. 2018;100:294-313.

131. Guo J, Anton ES. Decision making during interneuron migration in the developing cerebral cortex. Trends Cell Biol. 2014;24:342-51.

132. Marin O, Valiente M, Ge X, Tsai LH. Guiding neuronal cell migrations. Cold Spring Harb Perspect Biol. 2010;2:a001834.

133. Peyre E, Silva CG, Nguyen L. Crosstalk between intracellular and extracellular signals regulating interneuron production, migration and integration into the cortex. Front Cell Neurosci. 2015;9:129.

134. Rymar VV, Sadikot AF. Laminar fate of cortical GABAergic interneurons is dependent on both birthdate and phenotype. J Comp Neurol. 2007;501: 369-80.

135. Sahara S, Yanagawa Y, O'Leary DD, Stevens CF. The fraction of cortical GABAergic neurons is constant from near the start of cortical neurogenesis to adulthood. J Neurosci. 2012;32:4755-61.

136. Akbarian S, Kim JJ, Potkin SG, Hetrick WP, Bunney WE Jr, Jones EG. Maldistribution of interstitial neurons in prefrontal white matter of the brains of schizophrenic patients. Arch Gen Psychiatry. 1996;53:425-36.

137. Akbarian S, Vinuela A, Kim JJ, Potkin SG, Bunney WE Jr, Jones EG. Distorted distribution of nicotinamide-adenine dinucleotide phosphate-diaphorase neurons in temporal lobe of schizophrenics implies anomalous cortical development. Arch Gen Psychiatry. 1993;50:178-87. 
138. Akbarian S, Bunney WE Jr, Potkin SG, Wigal SB, Hagman JO, Sandman CA, et al. Altered distribution of nicotinamide-adenine dinucleotide phosphate-diaphorase cells in frontal lobe of schizophrenics implies disturbances of cortical development. Arch Gen Psychiatry. 1993;50:169-77.

139. Tricoire L, Pelkey KA, Erkkila BE, Jeffries BW, Yuan X, McBain CJ. A blueprint for the spatiotemporal origins of mouse hippocampal interneuron diversity. J Neurosci. 2011;31:10948-70.

140. Heckers S, Konradi C. GABAergic mechanisms of hippocampal hyperactivity in schizophrenia. Schizophr Res. 2015;167:4-11.

141. Konradi C, Zimmerman El, Yang CK, Lohmann KM, Gresch P, Pantazopoulos $H_{,}$ et al. Hippocampal interneurons in bipolar disorder. Arch Gen Psychiatry. 2011;68:340-50.
142. Heckers S, Stone D, Walsh J, Shick J, Koul P, Benes FM. Differential hippocampal expression of glutamic acid decarboxylase 65 and 67 messenger RNA in bipolar disorder and schizophrenia. Arch Gen Psychiatry. 2002;59:521-9.

143. Hackos DH, Lupardus PJ, Grand T, Chen Y, Wang TM, Reynen P, et al. Positive allosteric modulators of GluN2A-containing NMDARs with distinct modes of action and impacts on circuit function. Neuron. 2016;89:983-99.

144. Volgraf $M$, Sellers BD, Jiang $Y, W u$ G, Ly CQ, Villemure $E$, et al. Discovery of GluN2A-selective NMDA receptor positive allosteric modulators (PAMs): tuning deactivation kinetics via structure-based design. J Med Chem. 2016;59: 2760-79.

145. Kaiser T, Ting JT, Monteiro P, Feng G. Transgenic labeling of parvalbuminexpressing neurons with tdTomato. Neuroscience. 2016;321:236-45. 